Relations industrielles

Industrial Relations

\title{
Challenges for Work and Workers in the Knowledge Economy
} Introduction

\section{Défis pour le travail et les travailleurs dans une économie du} savoir

\section{Introduction}

\section{Larry Haiven}

Volume 69, numéro 1, hiver 2014

URI : https://id.erudit.org/iderudit/1024209ar

DOI : https://doi.org/10.7202/1024209ar

Aller au sommaire du numéro

Éditeur(s)

Département des relations industrielles de l’Université Laval

ISSN

0034-379X (imprimé)

1703-8138 (numérique)

Découvrir la revue

Citer ce document

Haiven, L. (2014). Challenges for Work and Workers in the Knowledge

Economy: Introduction / Défis pour le travail et les travailleurs dans une

économie du savoir : introduction. Relations industrielles / Industrial Relations,

69(1), 115-135. https://doi.org/10.7202/1024209ar

Tous droits réservés @ Département des relations industrielles de l’Université Laval, 2014
Ce document est protégé par la loi sur le droit d'auteur. L'utilisation des services d'Érudit (y compris la reproduction) est assujettie à sa politique d'utilisation que vous pouvez consulter en ligne.

https://apropos.erudit.org/fr/usagers/politique-dutilisation/ 


\section{SYMPOSIUM: CHALLENGES FOR WORK AND WORKERS IN THE KNOWLEDGE ECONOMY}

\section{Introduction}

\section{Larry Haiven}

The three articles that follow comprise a "symposium" within this issue of the journal. They emerge from the international conference Challenges for Work and Workers in a Knowledge Economy/Défis pour le travail et les travailleurs dans une économie du savoir held in Halifax, Nova Scotia in December $2010^{1}$ and sponsored by, among others, the Centre de recherche interuniversitaire sur la mondialisation et le travail (CRIMT) and the Social Sciences and Humanities Research Council of Canada (SSHRC).

The conference investigated the challenges for all stakeholders in the emerging world of knowledge work and focused on the following subthemes and questions:

- Representation: What new players and institutional forms are emerging and how is the struggle to organize both work and workers being redefined?

- Public Policy and Law: Does the regulation of existing institutions adequately serve the needs of workers and employers/deployers of labour in the knowledge economy?

- Working conditions, careers and the labour process: How are working conditions and the labour process shaped by the identities, norms and expectations of knowledge workers and the knowledge economy?

- Immaterial labour and ownership of intellectual property: What impact does the blurring of the production/consumption boundary have on work control and workplace relations?

- Managing knowledge workers: How do you manage knowledge workers, or creative workers, or semi-autonomous professionals collaborating with peers, owners and managers? Where are managers' sources of power and legitimacy?

The following articles explore these issues through the study of three very different industrial milieux: video game production, state criminal prosecution and co-operatives seized by the workers from delinquent owners. In all three, the workers and their knowledge play a crucial role in the success or failure of the enterprise. In all three, workers canvass the emancipatory opportunities available to them to fight for greater control and less exploitation. The three articles move from more informal to more formal worker organization, from weaker (but 
still important) forms of interest representation to more powerful forms of selfemancipation and, ultimately, to ownership and self-management.

A key question running through the symposium is: In a world where value is decreasingly created from making "things" and increasingly created by the strategic manipulation of information, data, images and ideas, how relevant are trade unions, what other forms of representation are emerging and can all of these organizations work together to further or, alternatively, work against one another to subvert the interests of workers?

These debates emerge amid a poverty of theory in organization studies. Even among critical organizational theorists, the focus is, as ever, on the individual actors in the workplace: employer and the employee (Jacques, 1996). Even trenchant Marxist analyses of the modern labour process like that of Braverman (1974) often see workers as responding almost without relevant collective voice to the calculations and depredations of management. Even the large body of literature on industrial relations (Kelly, 1998; Kaufman, 2004; Blyton et al., 2008) is locked in a box that tends to see unions as the only collectivity worth studying and collective bargaining as the highest form of collective action. Industrial relations scholars tend to avoid other organizational forms. They also have a blind spot for both informal and subdued resistance as well as more explosive and ephemeral reactions to management authority (Edwards, 1986 and Fantasia, 1988 as notable exceptions).

A similarly large scholarly thrust studying professionalization (Abbott, 1988; Freidson, 1986; Larson, 1977) has virtually ignored trade unions, concentrating on professional societies. And little, if any, research devotes itself to the inter-relation among unions, professional societies and other forms of worker collectivity. Moreover, despite the growth of dependent self-employment (Muehlberger, 2007), the vast majority of work on labour regulation assumes a direct legal employment relationship between a worker and the institution that provides him with the work opportunity and payment for it.

And yet, simple observation should tell us that many workers, especially skilled workers, belong to a number of different and cross-cutting, competing and collaborating interest organizations. A particularly good example occurs in the health specialties. For nurses and medical technologists, for example, their work may be regulated by no less than four different institutions²:

1. An employer will have a large say on their terms and conditions of work;

2. If employed, they may be members of a trade union and subject to collective bargaining;

3. Their initial credentialization and continuing licence to practice may be regulated by a college or order; 
4. The promotion of their specialty and professional development may be provided by a professional association.

Anybody seriously studying the work of these occupations or the regulation of labour in health care would be foolish to ignore any of these interest organizations and the inter-relationship among them.

And what about where a traditional legal employment relationship is missing, where the worker performs not under a contract of service but rather under a contract for services? In this situation there are yet several interest organizations to represent workers. Professional performers like actors and musicians, though often self-employed, rely on guilds or unions to negotiate terms of service and remuneration with those who provide work opportunities. The completion of an apprenticeship and full membership in these organizations may signify that the member is finally a "professional" in her field. The same or other organizations may provide the performers with benefits, professional advancement and other rewards (for more on this, see Campbell and Haiven, 2012).

Finally, there is a further form of worker interest representation which has received scant attention from students of work - the co-operative, and especially the worker co-operative. The other forms mentioned above all assume that some capitalist or state enterprise (be it an employer or a contractor) owns and deploys the capital through which the workers are retained and set to work. But what of the situation where the workers themselves, either ab initio, or due to abandonment by capital, own and self-manage the enterprise where they work? Are co-operatives not another form of worker collectivity, erected by workers as a result of the ravages or the failures of the market?

In short, worker collectivity and its various forms, and the relationship among trade unions and those various forms, cry out desperately for further study and theory. The presentations in the "Challenges" conference and the articles in this symposium make a modest start in so doing.

How shall we begin to understand that inter-relationship? In an article cited by the several authors in this symposium (Haiven, 2006), I have limned the boundaries of a "union zone" where trade unions are most likely to be found and a "non-union zone" where the opposite applies. To begin with, I eschewed the use of the term "employer," which would imply a legal employment relationship only, and preferred to denote the provider of work opportunities as the "deployer."

I have situated the "union zone" within a matrix of two dimensions (figure 1): on the one axis is the level of worker skill and autonomy; on the other is the need for "mutuality" (i.e. how much the deployer must rely on the workers to participate in the coordination of the work process). 


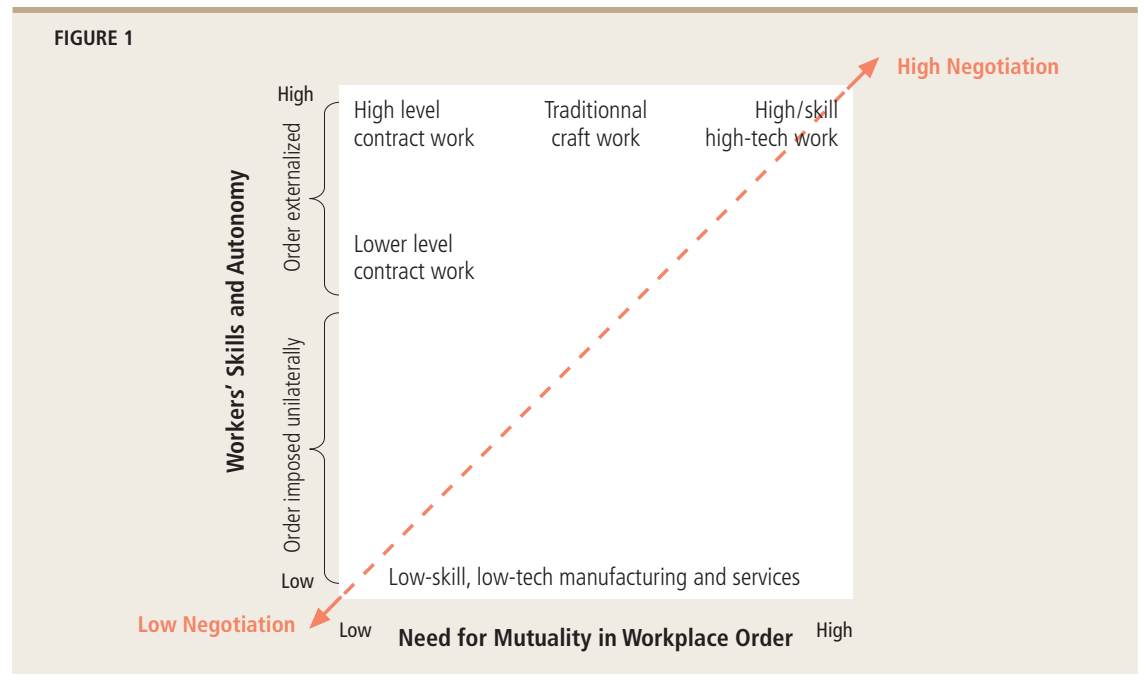

At the same time, I have posited that all work relationships, even those at the low end of both axes, are subject to negotiation at some level of intensity between those doing the work and those directing the work. At the low end of both axes, the level of negotiation is quite low. As both axes increase, the level of negotiating intensity rises, achieving its zenith in the upper right corner of the matrix, where mutuality and worker autonomy are both high.

\section{FIGURE 2}

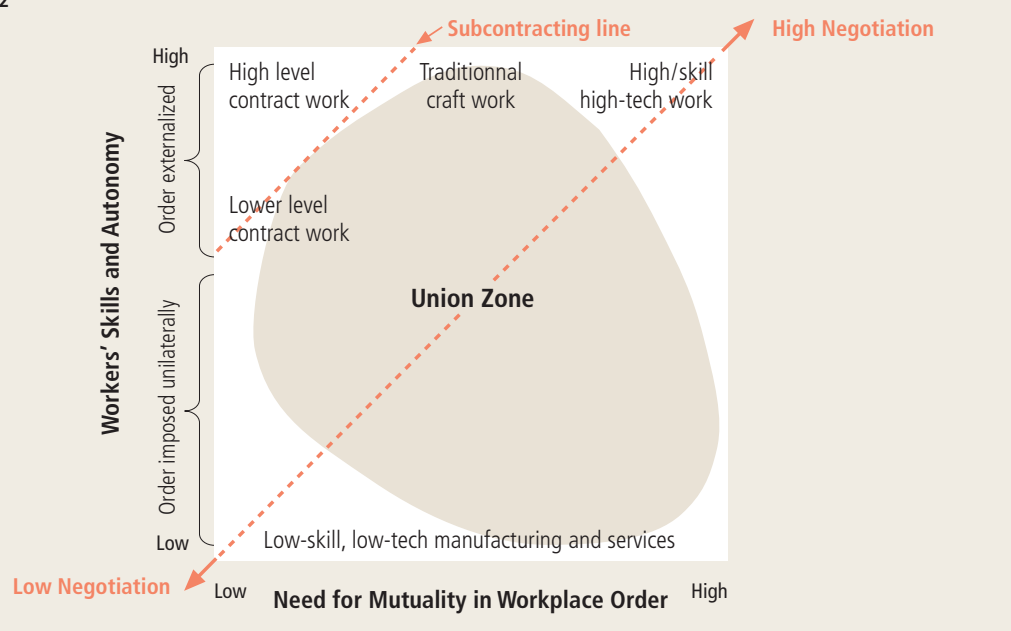

However, the intensity of negotiation is not synonymous with collective bargaining under trade unions. Indeed, in the upper right corner of the matrix, workers are so independent that individual bargaining prevails over collective bargaining. Workers are prone to negotiate on their own with their employer. 
Leftward, along the top of the matrix, where worker autonomy and independence are high, we move toward a situation where employment ceases and self-employment begins. The line where this change occurs could be called the "subcontract line." In the upper left corner, where worker autonomy is high but mutuality is low, the deployer merely subcontracts for the service of the workers and no employment relationship is manifest. "Taking care of business" is left up to the worker.

While the intensity of negotiation rises as we approach the upper right, the key to locating the "union zone" is how necessary and helpful collective (as opposed to individual) bargaining is to both employees and employer. The "union zone" can be found where terms and conditions of work best lend themselves to collective solutions, or by corollary, the "non-union zone" occurs as follow: a- (upper left) where unions are not protected by law; b- (upper right) where individual negotiation is more expedient; or, c- (bottom) where the power imbalance between workers and employer are greatest.

The article goes on to argue that collective organization may well thrive in the non-union zones, but not precisely in the union form. Among the individualistic skilled workers in the upper right, a collective organization could provide all sorts of professional development and career advancement that employers/deployers either do not or cannot provide. For the self-employed workers in the upper left, a collective organization can still provide some bargaining power, not over conditions of work but conditions of output e.g. prices. As well, it can provide benefits through its mass buying power.

Despite being remote from the traditional union zone, the potential for collective action along the top of our chart is great because of the presence of an "occupational community" among the groups of workers. Campbell, in one of the three articles in this symposium, describes occupational community thus:

An occupational community (OC) brings together professionals with shared interests, employment conditions, employer, or technical discipline and forges personal relationships that support the individuals and their careers (Salaman, 1971a; Van Maanen and Barley, 1984). In addition to the bonds of the broader profession itself, an OC develops around the unique characteristics of a particular group of workers.

In conclusion of my article (Haiven, 2006), I argued that far from shunning or disregarding non-union organizations as it has in the past, the labour movement ought to enter into coalitions, work alongside and increase its own scope of action to emulate these other types of organization.

An example of such a multi-faceted body, the Canadian Alliance of Cinema, Television and Radio Artists (ACTRA), a majority of whose members are selfemployed, acts as many professional organizations: a forum for apprenticeship, 
a professional development society, a collective bargaining agent for a floor of common protections (beyond which its members can negotiate individually), and a copyright collective finding and collecting royalties from the re-play of its members performances on electronic media. As well, it provides or co-sponsors fraternal insurance benefits, financial, and retirement facilities. Moreover, it encourages and supports its members to create, produce and self-manage their own artistic productions.

\section{A range of worker collectivity}

The three articles that follow further explore the range of organizational forms open to collectivities of workers. The first article, by Marie-Josée Legault and Johanna Weststar, is entitled "Comment jouer la régulation dans l'industrie du jeu vidéo?" In the burgeoning video game industry, perhaps an ideal type for the new economy, the intertwining of the roles of consumption and creation is a key to the production of a highly popular and profitable form of intellectual property. But the workers are subject to long, sometimes brutally long, hours (often without commensurate pay) and high-pressure last-minute demands.

The skill and experience of video game developers are essential factors in the survival of the industry and one would think that their very essentiality would give them great potential bargaining power. But this is also their Achilles Heel. They are so invested personally and professionally in the gaming adventure and life style, where it is said they are "paid to play," they find it very difficult to act collectively in their own interest, as opposed to those of their employers.

Using Kelly's (1998) provocative discussion of preconditions to collective action, the authors ponder why this may be so and why unionization seems so difficult. Several of Kelly's preconditions do prevail, but several crucial ones are not strongly evident: a group of workers must not only find certain working conditions harmful to their interests, but they must also find those conditions illegitimate and see management as the cause of their misfortune. The video game developers also see the solidarism of traditional trade unionism on offer very much antithetical to their meritocratic self-image as bold and independent creators.

Despite the difficulties in unionizing, the authors do discover several collective approaches among these workers. The International Game Developers Association (IGDA) serves as a forum of professional development, but also as a compendium of grievances, a conductor of worker surveys, and purports to set industrial standards (though employers are affected by moral suasion only.) Noting that the "Wagnerist" model of union recognition prevalent since the 1930's in North America is ill-suited to the game development industry and others like it, the authors call for a "new form of unionism." 
The second article, by Shelagh Campbell, is entitled: "Erosion and Renewal of Professional Powers in Public Sector Employment: The Role of Occupational Community." It focuses on Canadian Crown Attorneys (or State prosecutors), especially those in the province of Nova Scotia. Unlike many other lawyers, who are self-employed and pursue relative autonomy in their work, prosecutors are now employed in large government bureaucracies and subject to rules, procedures and control. And yet, the prosecutors' job demands a high level of both discretion and creativity - a seeming paradox. The clash between these two conditions breeds discontent and the urge to collective action among the occupational community of prosecutors.

Denied the legal right to join a trade union and bargain collectively until $2007^{3}$, they nonetheless organized themselves, demanded negotiations and went on strike illegally in 1998, shutting down the courts for two days. This led to the Nova Scotia government voluntarily recognizing the prosecutors' association and agreeing to an independent salary-setting forum. Similar arrangements now prevail for prosecutors across the country. Campbell capitalizes on the opportunity provided by the prosecutors to ponder the intersection of professionalization and unionization. As mentioned above, the various lines of inquiry into worker collective action have seldom, if ever, jibed to explore this intersection.

Campbell resurrects the invaluable work of Frank Parkin (1979) on closure theory. Parkin posits that elite groups who have special education and skills employ a strategy of exclusionary closure to exclude the non-credentialed from the privileges they themselves enjoy. They make pacts with the State whereby they provide guarantees of performance and probity in return for legal protection of their monopoly of practice. Such is the case among so-called "full" professions like medicine and law. Such legal protection is sought (but not always achieved in full) by others in the process of professionalization. Other groups, like trade unions, use a very different technique of usurpationary closure whereby they storm the citadels of power to wrest concessions and economic advantages. The modus operandi of the aspiring usurpers is usually more confrontational than that of the excluders - strikes, demonstrations and civil unrest. Parkin, however, suggests a third kind of closure, dual closure, whereby groups use both exclusionary and usurpationary tactics. The prosecutors of Campbell's study in this collection are excellent examples of that, at one and the same time maintaining exclusivity and practicing civil disobedience.

Campbell and Haiven (2012), in an article examining several professions, showed that, far from professionalism and unionism being separate or at odds with each other, over the past several decades some of the most epic and ground-breaking labour battles in Canada have been waged precisely by groups of professionalizing workers (e.g. nurses, lawyers, teachers, actors) over issues of professional identity such as scope of practice, breadth of discretion and the 
well-being of clients. As Campbell says in the present article "professionalization, collective bargaining, and occupational community are all instruments used by prosecutors in an attempt to control their labour process."

The third article, by Marcello Vieta is called: "Learning in Struggle: Argentina's New Worker Cooperatives as Transformative Learning Organizations". Unlike in the other two articles of this symposium, the workers here do not fit as easily, on the face of it, into the category of knowledge workers. Of the four workplaces, in two (a print shop, waste recycling) the work might well be considered manual while in two others (a newspaper, a medical clinic) at least some of the workers would be engaged in manual labour. But what they do as part of their job is not the point here. These are all worker co-operatives and the knowledge work common to all four is the collective governance and management of the enterprise. The sustainability of these enterprises is just as dependent upon this knowledge as upon any particular output emerging from them. Not only are the worker-owners engaged in ordinary self-governance, such as exist in Italian and Basque worker co-ops, they are still within about a decade of the explosive takeover, where they fought with, litigated against, negotiated with and lobbied for concessions from former employers, government and financial institutions.

Very truly, they are finding the road as they build it. The particular kind of knowledge developed here is what MacPherson calls "associative intelligence": "a special kind of knowing that emerges when people work together effectively; a conviction that people through working together could learn skills that would make collective behaviour more economically rewarding, socially beneficial and personally satisfying" (MacPherson, 2002: 90). Associative intelligence, like many other kinds of knowledge, is not only a corpus of facts, techniques and connections. It is also the collective confidence that its adepts gain by working and solving problems together.

This is very different than in the other two articles, where a work institution owned by others attempts to "pick the brains" of its workers to maximize the returns from their knowledge. There, the project of worker emancipation barely leaves the ground as the parties argue about the terms of servitude. Here, the workers have launched themselves into a totally new and different venture. Moreover, the author states, the struggle to take over the enterprises, to keep them as going concerns and to self-manage involve three social transformations: the transformation of the workers, the transformation of the work organization and the transformation of their communities.

Without doubt, the three articles in this symposium together, as diverse as they are, constitute an opening salvo in a coming field of research on the multiplicity of worker collectivity, a field which should produce an intellectual transformation in addition to those mentioned above: a transformation in the dominant paradigms of industrial relations. 


\section{Notes}

1 The conference and this symposium deliberately avoid the issue of how to define the "knowledge economy" and "knowledge work." Several authors have explored the boundaries of this phenomenon (e.g. Drucker, 1959; Davenport, 1999; Mosco and McKercher, 2007; Reinhardt et al., 2011). For the purposes of this symposium and for simplicity, we will use Drucker's very broad 1959 definition as those who deal primarily with knowledge (as opposed to physical objects) and the manipulation of information.

2 Some of these individual functions can sometimes be collapsed into a single organization. For example, teachers' unions often license and discipline their members and provide collective bargaining services to them, as well as provide professional development. See Haiven (1999).

3 That was the year of the Supreme Court of Canada decision Health Services and Support Facilities Subsector Bargaining Assn. v. British Columbia, 2007 SCC 27. This decision declared denial of collective bargaining rights unconstitutional.

\section{References}

Abbott, Andrew. 1988. The System of Professions. An Essay on the Division of Expert Labor. Chicago: The University of Chicago Press.

Blyton, Paul, Edmund Heery, Nicolas Bacon and Jack Fiorito. 2008. The SAGE Handbook of Industrial Relations, Los Angeles, London: Sage.

Braverman, Harry. 1998. Labor and Monopoly Capital. New York: Monthly Review Press.

Campbell, Shelagh and Larry Haiven. 2012. "Struggles on the Frontier of Professional Control: Leading Cases from Canada." Economic and Industrial Democracy. 33 (4): 669-689.

Davenport, Thomas O. 1999. Human Capital: What It Is and Why People Invest It. Jossey-Bass: San Francisco.

Drucker, Peter F. 1959. Landmarks of Tomorrow: A Report on the New 'Post-Modern' World. Harper \& Row: New York.

Edwards, Paul. 1986. Conflict at Work: A Materialist Analysis of Workplace Relations. Oxford: Basil Blackwell.

Fantasia, Rick. 1998. Cultures of Solidarity: Consciousness, Action and Contemporary American Workers. Berkeley, University of California Press.

Freidson, Eliot. 1986. Professional Powers. A Study of the Institutionalization of Formal Knowledge. Chicago: University of Chicago Press.

Haiven, Larry. 1999. "Professionalization and Unionization among paramedical professions: National regulation and the challenge of globalization". Unpublished paper. College of Commerce, University of Saskatchewan.

Haiven, Larry. 2006. "Expanding the Union Zone: Union Renewal through Alternative Forms of Worker Organization." Labor Studies Journal. 3 (3): 85-116.

Jacques, Roy. 1996. Manufacturing the Employee: Management Knowledge from the $19^{\text {th }}$ to the $21^{\text {st }}$ Century. London, Sage.

Kaufman, Bruce E. 2004. Theoretical Perspectives on Work and the Employment Relationship. Ithaca, N.Y.: Blackwell. 
Kelly, John. 1998. Rethinking Industrial Relations. Mobilization, Collectivism and Long Waves, London: Routledge.

Larson, Magali Sarfati. 1977. The Rise of Professionalism: A Sociological Analysis. Berkeley: University of California Press.

MacPherson, Ian. 2002. "Encouraging Associative Intelligence: Co-operatives, Shared Learning and Responsible Citizenship." Journal of Co-operative Studies, 35 (2): 86-98.

Mosco, Vincent and Catherine McKercher. 2007. "Introduction: Theorizing Knowledge Labor and the Information Society". Knowledge Workers in the Information Society. Lanham, Lexington Books.

Muehlberger, Ulrike. 2007. Dependent Self-Employment: Workers in the Border between Employment and Self-Employment. London: Palgrave Macmillan.

Parkin, Frank. 1979. Marxism and Class Theory: A Bourgeois Critique. New York: Columbia University Press.

Reinhardt, Wolfgang, Benedikt Schmidt, Peter Sloep and Hendrik Drachsler. 2011. "Knowledge Worker Roles and Actions: Results of Two Empirical Studies." Knowledge and Process Management, 18 (3): 150-174.

Salaman, Graeme. 1971a. "Some Sociological determinants of occupational communities." Sociological Review, 19 (1): 53-77.

Van Maanen, John and Stephen R. 1984. "Occupational communities: Culture and control in organizations." Research in Organizational Behavior, 6: 287-365. 


\section{SYMPOSIUM : DÉFIS POUR LE TRAVAIL ET LES TRAVAILLEURS DANS UNE ÉCONOMIE DU SAVOIR}

\section{Introduction}

\section{Larry Haiven}

Les trois articles qui suivent constituent un « symposium »» intégré au présent numéro. Ils proviennent de la Conférence internationale Challenges for Work and Workers in a Knowledge Economy/Défis pour le travail et les travailleurs dans une économie du savoir qui s'est tenue à Halifax, en Nouvelle-Écosse, en décembre $2010^{1}$. L'événement était commandité, entre autres, par le Centre de recherche interuniversitaire sur la mondialisation et le travail (CRIMT) et le Conseil de recherches en sciences humaines du Canada (CRSH).

Cette conférence portait sur les défis rencontrés par les acteurs de l'économie du savoir, un secteur actuellement en plein développement. Elle s'est centrée sur les questions thématiques suivantes:

- Représentation : Quels sont les nouveaux acteurs et les formes institutionnelles émergentes de l'économie du savoir? Et comment redéfinissent-ils l'organisation du travail et la lutte des travailleurs?

- Droit et politiques publiques : La réglementation des institutions est-elle adaptée aux besoins des travailleurs et à ceux des employeurs et des « déployeurs » dans l'économie du savoir?

- Conditions de travail, carrière et processus du travail : Comment les identités, les normes et les attentes des travailleurs du savoir influencent-elles les conditions et le processus de travail dans l'économie du savoir?

- Travail immatériel et propriété intellectuelle : Quel est l'impact de l'atténuation de la frontière entre la production et la consommation sur le contrôle du travail et les relations en milieu de travail?

- Gestion des travailleurs du savoir : Comment gérer les travailleurs du savoir, les créateurs ou les professionnels semi-autonomes qui collaborent avec des collègues, des propriétaires et des gestionnaires? Quelles sont les sources de pouvoir et de légitimité des gestionnaires?

Les articles ci-dessous analysent ces enjeux en étudiant trois milieux très différents : le monde de la production des jeux vidéo, le travail des Procureurs de la Couronne ainsi que la situation dans des coopératives créées à la suite d'une reprise d'entreprise par ses travailleurs. Dans les trois cas, le savoir des travailleurs 
s'avère déterminant pour la réussite ou l'échec de l'entreprise, et les travailleurs examinent les possibilités d'émancipation à leur portée afin d'obtenir une autonomie accrue et de réduire leur exploitation. Les trois articles vont d'une organisation des travailleurs informelle à plus formelle, d'une forme faible (mais néanmoins importante) de défense de leurs intérêts à un modèle d'émancipation plus puissant et, enfin, à l'accession à la propriété et l'autogestion.

La question centrale qui revient dans ce symposium est la suivante : Dans un monde où la création de valeur repose de moins en moins sur la fabrication d'objets et de plus en plus sur le traitement stratégique de l'information, des données, des images et des idées, quelle est l'efficacité des syndicats, quelles autres formes de représentation émergent et, enfin, ces différentes organisations vont-elles collaborer à la défense des intérêts des travailleurs ou, autrement, s'engageront-elles dans une lutte ayant pour effet de miner les droits de ces derniers?

Ce débat surgit dans un contexte de pauvreté théorique à l'intérieur du champ de l'étude des organisations. Même les théoriciens critiques de ce domaine articulent, généralement, leur réflexion autour des acteurs individuels du milieu de travail, c'est-à-dire l'employeur et l'employé (Jacques, 1996). Même les analystes marxistes les plus critiques à l'endroit du monde moderne du travail, notamment Braverman (1974), supposent la quasi-absence de toute concertation des travailleurs en réaction aux calculs et aux mesures discutables de leurs gestionnaires. Même le vaste corpus traitant des relations industrielles (Kelly, 1998; Kaufman, 2004; Blyton et coll., 2008) présente une vision étroite selon laquelle seuls les syndicats constitueraient I'unique organe collectif digne d'intérêt, et la négociation des conventions collectives comme la meilleure forme d'action concertée. Ces mêmes spécialistes ont tendance à ignorer les autres formes d'organisation. Ils comprennent peu tant les manifestations de résistance, informelle et prudente, que la contestation, explosive et éphémère, à l'endroit de leurs dirigeants (à l'exception notable d'Edwards, 1986 et de Fantasia, 1988).

De même, un nombre important de penseurs qui étudient la professionnalisation (Abbott, 1988; Freidson, 1986; Larson, 1977) ont pratiquement ignoré les syndicats, préférant se concentrer uniquement sur les associations professionnelles. On recense peu, voire pas, d'études sur les relations mutuelles entre les syndicats, les associations professionnelles et les autres formes de regroupement de travailleurs. De plus, malgré l'essor du travail autonome et du nombre de contractuels (Muehlberger, 2007), la vaste majorité des travaux sur la réglementation du travail postule l'existence d'une relation d'emploi directe et légale entre un travailleur et l'établissement qui lui offre un travail rémunéré.

Or, une simple observation nous apprend qu'un grand nombre de travailleurs, au premier chef les travailleurs qualifiés, adhèrent à plusieurs organismes d'inté- 
rêt professionnel qui sont distincts et transversaux, concurrents ou collaborateurs. Le secteur des soins de santé spécialisés en constitue un bon exemple. En effet, le travail des infirmiers et des technologues médicaux peut être régi de quatre manières différentes ${ }^{2}$ :

1. I'employeur peut définir dans une large mesure leurs conditions de travail;

2. ceux qui ont le statut d'employé peuvent être membres d'un syndicat et assujettis à une convention collective;

3. ils peuvent détenir un titre professionnel ou un permis d'exercer régi par un ordre professionnel;

4. la promotion de leur spécialité et leur perfectionnement professionnel peuvent être gérés par une association professionnelle.

Toute personne, qui prétend à une étude sérieuse de ces professions ou de la réglementation du travail dans le domaine des soins de santé, serait malvenue de ne pas tenir compte de ces organismes d'intérêt professionnel et de leurs interrelations.

Et qu'en est-il des travailleurs qui n'ont aucune relation traditionnelle d'emploi au sens de la loi, qui sont régis, non pas par un contrat de travail, mais par un contrat de services? Dans cette situation, il y a bel et bien plusieurs organismes d'intérêt professionnel qui représentent les travailleurs de cette catégorie. Ainsi, les professionnels de la scène, notamment les acteurs et les musiciens, généralement des travailleurs indépendants, peuvent compter sur des guildes ou des syndicats pour négocier leurs contrats de service et leur rémunération avec les donneurs d'ouvrage. L'accomplissement d'un stage et l'accès au statut de membre de ces organismes peuvent conduire à un « titre professionnel » dans ce domaine. L'organisme en question ou un autre peut offrir aux professionnels de la scène des avantages sociaux, des occasions de perfectionnement professionnel ainsi que d'autres avantages (pour un complément d'information, se reporter à Campbell et Haiven, 2012).

Enfin, il existe une autre forme de défense des travailleurs qui n'a guère suscité l'intérêt de ceux qui étudient le travail : la coopérative, plus particulièrement la coopérative de travailleurs. Les structures décrites ci-dessus se fondent toutes sur le modèle d'une entreprise capitaliste ou publique (qu'elle soit l'employeur direct ou le sous-traitant) qui possède et déploie les capitaux permettant de conserver et de faire travailler une main-d'œuvre. Mais qu'en est-il dans le cas où ce sont les travailleurs qui possèdent et qui gèrent l'entreprise où ils travaillent, soit depuis sa création, soit à la suite de l'abandon du capital? Les coopératives ne sont-elles pas une autre forme de regroupement de travailleurs, créé par eux en réaction aux ravages ou aux échecs du marché? 
En somme, les diverses formes de regroupement de travailleurs et leurs rapports avec les syndicats constituent un champ d'études encore vierge. Les exposés de la Conférence Challenges for Work and Workers in a Knowledge Economy / Défis pour le travail et les travailleurs dans une économie du savoir ainsi que les articles du présent corpus représentent un modeste premier pas dans ce territoire inexploré.

Par où débuter pour comprendre cette relation d'interdépendance? Dans un article cité par les auteurs du présent corpus d'articles (Haiven, 2006), j'ai délimité les contours d'une "zone syndiquée », sorte de champ d'action des syndicats, et d'une "zone non syndiquée » dont ils sont absents. D'emblée, j'ai évité le terme " employeur», qui se limite aux relations d'emploi légal, lui préférant le terme « déployeur » pour désigner le donneur d'ouvrage. J'ai situé la «zone syndiquée » à l'intérieur d'une matrice à deux dimensions (voir figure 1) : sur un axe, le degré de qualifications et d'autonomie des travailleurs; sur l'autre, le besoin de " mutualité » (c'est-à-dire la mesure dans laquelle le " déployeur » dépend de la participation des travailleurs à la coordination du processus du travail).

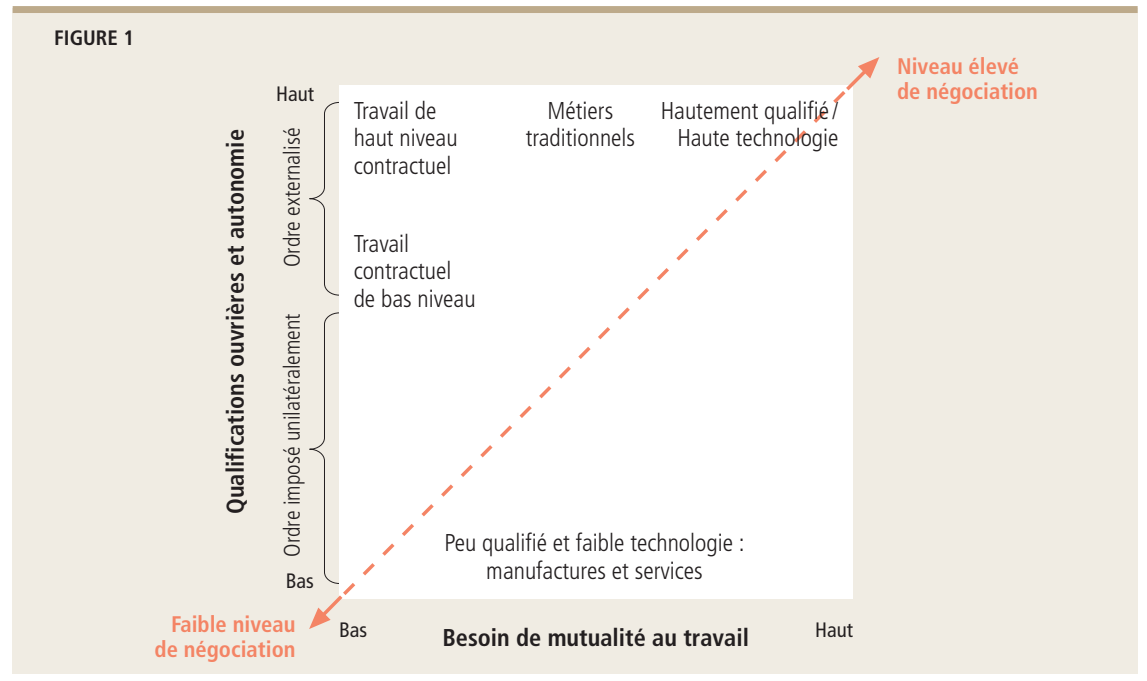

Parallèlement, j'ai postulé que toutes les relations de travail, même celles qui se situent aux extrémités inférieures des deux axes, font l'objet de négociations plus ou moins intenses entre ceux qui exécutent les tâches et ceux qui les dirigent. Aux extrémités inférieures des deux axes, le degré de négociation est assez faible; à mesure qu'on remonte les deux axes, les négociations s'intensifient, atteignant leur apogée dans le coin supérieur droit de la matrice, où la mutualité et l'autonomie des travailleurs sont toutes deux élevées (voir figure 2). 


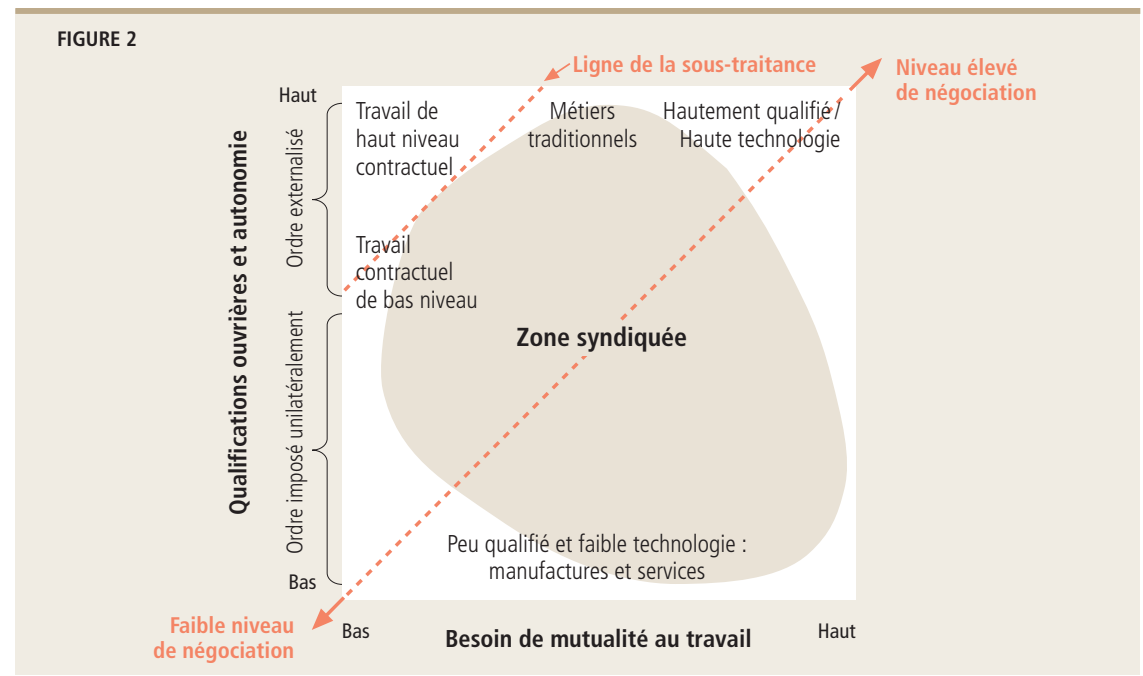

Cependant, l'intensité des négociations n'est pas synonyme de négociations collectives sous l'égide de syndicats. En effet, à l'extrémité supérieure droite de la matrice, l'indépendance des travailleurs est telle quec'estla négociation individuelle qui prévaut. Les travailleurs sont plutôt enclins à négocier personnellement avec leur employeur. À mesure qu'on se déplace vers la gauche de la matrice, le long de sa partie supérieure, où l'autonomie des travailleurs est élevée, on se rapproche d'une situation où l'emploi est remplacé par le travail indépendant. L'endroit où ce changement survient est appelé « ligne de sous-traitance ». Dans le coin supérieur gauche, où l'autonomie des travailleurs est maximale et la mutualité minimale, le " déployeur » confie simplement le service des travailleurs en soustraitance, sans aucune relation d'emploi manifeste. Le fardeau de la gestion du travail repose entièrement sur les épaules du travailleur.

Alors que l'intensité des négociations augmente à mesure qu'on s'approche du coin supérieur droit, pour délimiter la « zone syndiquée », il faut déterminer dans quelle mesure la négociation collective (par opposition à la négociation individuelle) est nécessaire et utile à la fois pour les employés et l'employeur. La "zone syndiquée " se situe là où les conditions de travail se prêtent le mieux à des solutions collectives ou, par corollaire, la zone non-syndiquée se situe aux endroits suivants : a- dans la partie supérieure gauche, où les syndicats ne sont pas protégés par la loi; b- dans la partie supérieure droite, où la négociation individuelle s'avère plus efficace; et c- dans la partie inférieure, où le déséquilibre du pouvoir entre les travailleurs et l'employeur est le plus marqué.

Dans la suite de cet article, j'affirme qu'une organisation collective peut prospérer dans les zones non-syndiquées, mais sous une forme différente 
de celle du syndicat. Auprès des travailleurs qualifiés et individualistes du coin supérieur droit, une organisation collective pourrait offrir toutes sortes d'occasions de perfectionnement et d'avancement professionnel que les employeurs et « déployeurs» ne souhaitent ou ne peuvent pas leur offrir. Pour les travailleurs indépendants situés dans la partie supérieure gauche, une organisation collective possède toujours un certain pouvoir de négociation, non pas à l'égard des conditions de travail, mais à l'endroit des conditions de la prestation, notamment des prix. De même, elle peut procurer des avantages certains à ces travailleurs grâce à son pouvoir d'achat de masse.

Bien qu'elle soit éloignée de la «zone syndiquée », la zone supérieure du graphique présente un fort potentiel d'action collective en raison de la présence d'une « communauté professionnelle » parmi ces groupes de travailleurs. Dans l'un des trois articles du présent corpus, Campbell définit la communauté professionnelle comme suit :

Une communauté professionnelle est un regroupement de professionnels ayant en commun des intérêts, des conditions d'emploi, un employeur ou une discipline spécialisée, qui crée un réseau de liens personnels en vue de soutenir les professionnels et leur carrière (Salaman, 1971a; Van Maanen et Barley, 1984). En plus des liens qui unissent les membres de la profession, la communauté professionnelle se développe autour des caractéristiques uniques d'un groupe particulier de travailleurs. [Traduction]

Dans la conclusion de mon article (Haiven, 2006), je soutiens qu'au lieu d'éviter ou d'ignorer les organisations non-syndicales comme il l'a fait dans le passé, le mouvement ouvrier a tout intérêt à créer des alliances et à collaborer avec ces dernières, et, en outre, il gagnerait à élargir son champ d'action, à l'instar de ces autres types d'organisations. Prenons l'exemple d'un organisme à vocation multiple présente surtout au Canada anglais, I'Alliance of Canadian Cinema, Television and Radio Artists, (ACTRA, en français, Alliance canadienne des artistes de cinéma, télévision et radio), dont la majorité des membres sont des travailleurs indépendants. Elle remplit plusieurs fonctions : un forum d'apprentissage, une société de perfectionnement professionnel, un agent négociateur d'un ensemble de conditions de base communes (que ses membres sont libres de renégocier individuellement) et une société de gestion des droits d'auteur chargée de trouver et de collecter les redevances pour la rediffusion des œuvres de ses membres dans les médias électroniques. De plus, l'organisme fournit ou cofinance une assurance mutuelle, une aide financière et un régime de retraite. Enfin, il encourage et soutient la création, la production et l'autogestion artistiques de ses membres. 


\section{Un éventail de collectivités ouvrières}

Les trois articles qui suivent examinent plus en profondeur les diverses formes d'organisations offertes aux divers groupes de travailleurs étudiés. Le premier article, par Marie-Josée Legault et Johanna Weststar, s'intitule « Comment jouer la régulation dans l'industrie du jeu vidéo? ». Dans ce secteur florissant, sans doute un idéal-type pour la nouvelle économie, le chevauchement de la consommation et de la création joue un rôle essentiel dans la production de cette forme très populaire et rentable de propriété intellectuelle. Or, les travailleurs doivent effectuer de longues, parfois extrêmement longues, journées de travail (souvent sans rémunération conséquente) et subissent une forte pression liée aux exigences de dernière minute.

Les compétences et l'expérience des concepteurs de jeux vidéo constituent des facteurs essentiels à la survie du secteur d'activités, et l'on pourrait croire que leur caractère indispensable leur procure un important pouvoir de négociation. Mais leur avantage est aussi leur talon d'Achille : ils sont tellement investis sur les plans personnel et professionnel dans la production de jeux et le mode de vie qui y est associé, alors qu'on les dit " payés pour jouer », qu'il leur est difficile d'agir collectivement dans leur propre intérêt, en opposition à celui de leur employeur.

S'appuyant sur l'analyse critique de Kelly (1998) relative aux conditions préalables à l'action collective, les auteures réfléchissent à leurs causes et aux raisons qui rendent la syndicalisation si difficile. Plusieurs des conditions préalables énoncées par Kelly prédominent effectivement, mais d'autres conditions cruciales ne sont pas aussi présentes : les travailleurs doivent, non seulement estimer que certaines conditions de travail vont à l'encontre de leurs intérêts, mais ils doivent aussi les trouver illégitimes et tenir la direction responsable de leur malheur. Aux yeux des concepteurs de jeux vidéo, la solidarité que propose le syndicalisme traditionnel s'avère être aux antipodes de leur propre image méritocratique de créateurs indépendants et audacieux.

Malgré leurs réserves à l'endroit des syndicats, les auteures recensent plusieurs structures collectives chez ces travailleurs. L'International Game Developers Association (IGDA) assume plusieurs rôles : elle offre un cadre de perfectionnement professionnel, tient un registre des griefs, réalise des sondages auprès des travailleurs et prétend établir les normes du secteur (bien qu'elle n'exerce qu'une pression morale sur les employeurs). Estimant que le modèle " wagnériste » de la reconnaissance syndicale qui prévaut en Amérique du Nord depuis les années 1930 est mal adapté au secteur de la production de jeux ainsi qu'à d'autres secteurs d'activité voisins, les auteures préconisent une « nouvelle forme de syndicalisme ». 
Le deuxième article, par Shelagh Campbell, s'intitule «Erosion and Renewal of Professional Powers in Public Sector Employment: The Role of Occupational Community ». L'auteure s'intéresse aux procureurs de la Couronne (les procureurs publics) du Canada, plus particulièrement à ceux de la province de la NouvelleÉcosse. Contrairement à bon nombre d'autres avocats, qui sont des travailleurs indépendants et jouissent d'une relative autonomie dans leur travail, les procureurs sont des employés de la fonction publique, assujettis aux règles, aux procédures et au contrôle de l'État. Or, la nature de leur travail fait appel dans une large mesure à leur pouvoir discrétionnaire et à leur créativité - un paradoxe apparent. Le conflit entre ces deux dimensions est source de mécontentement et pousse la communauté des procureurs à réclamer une action collective.

Alors que, jusqu'en $2007^{3}$, on leur refusait le droit d'adhérer à un syndicat et de négocier une convention collective, ils se sont néanmoins organisés, ont réclamé des négociations et ont déclenché une grève illégale en 1998, forçant la fermeture des tribunaux pendant deux jours. Ce geste a conduit le gouvernement de la Nouvelle-Écosse à accepter de reconnaître l'association des procureurs et de mettre sur pied un forum indépendant pour l'établissement des salaires. Aujourd'hui, les procureurs de l'ensemble du pays bénéficient de conditions similaires. En s'appuyant sur le cas des procureurs, Campbell réfléchit aux rapports entre professionnalisation et syndicalisation. Comme nous l'avons indiqué ci-dessus, les divers champs d'études de l'action collective des travailleurs ne se sont rarement, voire jamais, intéressés à ces rapports.

Campbell reprend les travaux précieux de Frank Parkin (1979) sur la « théorie de la fermeture ». Parkin y postule que les groupes d'élite ayant une formation et des compétences spécialisées emploient une stratégie de «fermeture par exclusion » pour empêcher les travailleurs non spécialisés de jouir des mêmes privilèges qu'eux. Ils signent des pactes avec l'État, à qui ils donnent des garanties de rendement et de probité en échange d'une protection juridique de leur monopole professionnel. C'est le cas des professionnels dits « reconnus» comme les médecins ou les juristes, tandis que d'autres réclament (sans toujours obtenir entièrement gain de cause) une protection juridique semblable dans le cadre d'un processus de professionnalisation. D'autres groupes, comme les syndicats, ont recours à une technique très différente : la «fermeture par usurpation », qui consiste à prendre $\mathrm{d}^{\prime}$ assaut les citadelles du pouvoir pour leur arracher des concessions et des avantages économiques. Le modus operandi des aspirants usurpateurs est généralement davantage axé sur la confrontation - grèves, manifestations et agitation civile sont leurs armes. Parkin décrit, toutefois, un troisième type de fermeture, la « double fermeture », qui recourt à la fois à l'exclusion et à l'usurpation. Les procureurs étudiés par Campbell en sont d'excellents exemples : ces derniers entretiennent l'exclusivité tout en pratiquant la désobéissance civile. 
Campbell et Haiven (2012), dans une étude portant sur plusieurs professions, ont montré que le professionnalisme et le syndicalisme sont loin d'être opposés ou en conflit; au cours des dernières décennies, les combats pour les droits des travailleurs les plus épiques et les plus marquants menés au Canada sont précisément l'œuvre de groupes de professionnels (notamment les infirmiers, les avocats, les enseignants et les acteurs) et ils portaient sur des enjeux d'identité professionnelle tels que le champ d'exercice, le pouvoir discrétionnaire et le bienêtre des clients. Comme l'indique Campbell dans son article : « la professionnalisation, la négociation collective et la communauté professionnelle sont autant d'instruments utilisés par les procureurs dans le but d'exercer un pouvoir sur leur processus de travail ». [Traduction]

Le troisième article, signé par Marcello Vieta, s'intitule "Learning in Struggle: Argentina's New Worker Cooperatives as Transformative Learning Organizations". Contrairement aux deux articles précédents, les travailleurs dont il est question ici n'entrent pas tout à fait, a priori, dans la catégorie des travailleurs du savoir. Des quatre lieux de travail étudiés, deux (une imprimerie et une usine de recyclage des déchets) emploient des travailleurs considérés comme manuels, et les deux autres (un journal et une clinique médicale) comptent au moins quelques travailleurs manuels. Or, la tâche des travailleurs n'est pas l'objet central de l'étude. II s'agit, en fait, de quatre coopératives de travailleurs, dont la gouvernance et la gestion collectives constituent le travail intellectuel. La durabilité de ces entreprises repose tout autant sur ce savoir que sur la production ou la prestation de services. Les travailleurs-propriétaires exercent une autogouvernance ordinaire, selon le modèle des coopératives de travailleurs italiennes et basques, et moins de dix ans se sont écoulés depuis leur prise de contrôle remarquée et les concessions qu'ils ont arrachées, au prix de combats, de litiges, de négociations et de pressions, à leurs anciens employeurs, au gouvernement et aux institutions financières.

En vérité, ils apprennent au fur et à mesure. Le type de savoir particulier qu'ils acquièrent relève de ce que MacPherson appelle "l'intelligence associative »: « [...] une forme particulière de savoir résultant de la collaboration efficace d'un groupe de personnes; la conviction que, par la collaboration, celles-ci peuvent acquérir des compétences qui rendraient le comportement collectif plus rentable sur le plan économique, avantageux sur le plan social et satisfaisant sur le plan personnel. (MacPherson, 2002 : 90) [Traduction] ». L'intelligence associative, comme bien d'autres types de savoir, ne saurait se résumer à un ensemble de faits, de techniques et de relations. Elle englobe également l'assurance collective qu'acquièrent ses adeptes en collaborant à la résolution de problèmes.

Cette situation diffère considérablement de celles que décrivent les deux articles précédents, où une organisation appartenant à d'autres personnes exploite 
la matière grise de ses travailleurs en vue de tirer le maximum de leur savoir. Dans de tels cas, le projet d'émancipation des travailleurs surgit à peine tandis que les parties débattent des conditions de leur servitude. Dans le cas des coopératives étudiées, les travailleurs se sont lancés dans une entreprise tout à fait nouvelle et différente. En outre, selon l'auteur, la lutte pour la reprise des entreprises afin d'en assurer la continuité de l'exploitation et l'autogestion implique trois transformations sociales : celle des travailleurs, celle de l'organisation du travail et celle des collectivités.

De toute évidence, les trois articles du présent symposium, aussi divers qu'ils soient, constituent les précurseurs d'un nouveau champ d'études sur la multiplicité des collectivités de travailleurs, un champ qui devrait amener une transformation intellectuelle, en plus de celles mentionnées précédemment, soit une transformation du modèle dominant des relations industrielles.

\section{Notes}

1 La Conférence, de même que le présent corpus d'articles, évitent délibérément de définir les notions d' « économie du savoir » et de " travailleur du savoir ». Plusieurs auteurs ont tenté de circonscrire ces phénomènes (Drucker, 1959; Davenport, 1999; Mosco et McKercher, 2007; Reinhardt et al., 2011). Aux fins du présent corpus d'articles et pour des questions pratiques, nous nous appuierons sur la définition générale élaborée par Drucker, en 1959, selon laquelle l'économie du savoir fait principalement appel à des connaissances (par opposition à des objets) et au traitement de l'information.

2 Certaines de ces fonctions sont parfois regroupées au sein d'un seul organisme. Par exemple, de nombreux syndicats d'enseignants délivrent les permis, exercent des mesures disciplinaires à l'encontre de leurs membres, négocient leurs conventions collectives et leur offrent des activités de perfectionnement professionnel. Voir Haiven (1999).

3 C'est l'année de l'Arrêt de la Cour Suprême du Canada, Health Services and Support - Facilities Subsector Bargaining Assn. c. Colombie-Britannique, 2007 CSC 27. La Cour a déclaré inconstitutionnel le refus du droit à la négociation collective.

\section{Bibliographie}

Abbott, Andrew. 1974. The System of Professions. An Essay on the Division of Expert Labor. Chicago: The University of Chicago Press.

Blyton, Paul, Edmund Heery, Nicolas Bacon and Jack Fiorito. 2008. The SAGE Handbook of Industrial Relations, Los Angeles, London: Sage.

Braverman, Harry. 1998. Labor and Monopoly Capital. New York: Monthly Review Press.

Campbell, Shelagh and Larry Haiven. 2012. "Struggles on the Frontier of Professional Control: Leading Cases from Canada." Economic and Industrial Democracy. 33 (4): 669-689.

Davenport, Thomas O. 1999. Human Capital: What It Is and Why People Invest It. JosseyBass: San Francisco. 
Drucker, Peter F. 1959. Landmarks of Tomorrow: A Report on the New 'Post-Modern' World. Harper \& Row: New York.

Edwards, Paul. 1986. Conflict at Work: A Materialist Analysis of Workplace Relations. Oxford: Basil Blackwell.

Fantasia, Rick. 1998. Cultures of Solidarity: Consciousness, Action and Contemporary American Workers. Berkeley, University of California Press.

Freidson, Eliot. 1986. Professional Powers. A Study of the Institutionalization of Formal Knowledge. Chicago: University of Chicago Press.

Haiven, Larry. 1999. "Professionalization and Unionization among paramedical professions: National regulation and the challenge of globalization". Unpublished paper. College of Commerce, University of Saskatchewan.

Haiven, Larry. 2006. "Expanding the Union Zone: Union Renewal through Alternative Forms of Worker Organization." Labor Studies Journal. 3 (3): 85-116.

Jacques, Roy. 1996. Manufacturing the Employee: Management Knowledge from the $19^{\text {th }}$ to the $21^{\text {st }}$ Century. London, Sage.

Kaufman, Bruce E. 2004. Theoretical Perspectives on Work and the Employment Relationship. Ithaca, N.Y.: Blackwell.

Kelly, John. 1998. Rethinking Industrial Relations. Mobilization, Collectivism and Long Waves, London: Routledge.

Larson, Magali Sarfati. 1977. The Rise of Professionalism: A Sociological Analysis. Berkeley: University of California Press.

MacPherson, Ian. 2002. "Encouraging Associative Intelligence: Co-operatives, Shared Learning and Responsible Citizenship." Journal of Co-operative Studies, 35 (2): 86-98.

Mosco, Vincent and Catherine McKercher. 2007. "Introduction: Theorizing Knowledge Labor and the Information Society". Knowledge Workers in the Information Society. Lanham, Lexington Books.

Muehlberger, Ulrike. 2007. Dependent Self-Employment: Workers in the Border between Employment and Self-Employment. London: Palgrave Macmillan.

Parkin, Frank. 1979. Marxism and Class Theory: A Bourgeois Critique. New York: Columbia University Press.

Reinhardt, Wolfgang, Benedikt Schmidt, Peter Sloep and Hendrik Drachsler. 2011. "Knowledge Worker Roles and Actions: Results of Two Empirical Studies." Knowledge and Process Management, 18 (3): 150-174.

Salaman, Graeme. 1971a. "Some Sociological determinants of occupational communities." Sociological Review, 19 (1): 53-77.

Van Maanen, John and Stephen R. 1984. "Occupational communities: Culture and control in organizations." Research in Organizational Behavior, 6: 287-365. 